\title{
Kebijakan Penghapusan Sanksi Administrasi Perpajakan sebagai Stimulus Peningkatan Penerimaan Negara dari Sektor Pajak (Studi Evaluatif Normatif Kebijakan Perpajakan Nasional)
}

\author{
F.C. Susila Adiyanta \\ Fakultas Hukum, Universitas Diponegoro \\ J1.Prof.Soedarto, SH Tembalang Semarang \\ susilafhundip@gmail.com
}

\begin{abstract}
Elemination of tax administration sanction is the government's efforts to expand the number of taxpayers to increase state revenues. Kebijakan penghapusan sanksi administrasi perpajakanis the removal of sanctions facility income tax an individual or entity. The abolition of interest on underpaid tax that can be enjoyed by the people who do not have a Taxpayer Identification Number (TIN) or who already have a TIN on January 1, 2008. With the kebijakan kebijakan kebijakan penghapusan sanksi administrasi perpajakan, the subject of taxes that do not have TIN are encouraged to register as taxpayers. However, government policy as a form of a taxpayer's facility is limited implementation until the end of 2008. Can occur, the program will be constrained if there is still a poor perception and assessment of public service officers who carried out the tax.
\end{abstract}

Keywords: tax administration sanction, tax revenues

\begin{abstract}
Abstrak
Eleminasi sanksi administrasi pajak adalah upaya pemerintah untuk memperluas jumlah wajib pajak untuk meningkatkan penerimaan negara. Kebijakan penghapusan sanksi administrasi penghapusan fasilitas sanksi pajak penghasilan perorangan atau badan. Penghapusan bunga atas pajak kurang bayar yang dapat dinikmati oleh orang-orang yang tidak memiliki Nomor Pokok Wajib Pajak (TIN) atau yang sudah memiliki TIN pada 1 Januari 2008. Dengan adanya kebijakan kebijakan, administrasi perpajakan pajak yang tidak memiliki NPW didorong untuk mendaftar sebagai pembayar pajak. Namun, kebijakan pemerintah sebagai bentuk fasilitas wajib pajak terbatas pelaksanaannya hingga akhir tahun 2008. Dapat terjadi, program akan terkendala jika masih ada persepsi dan penilaian buruk dari petugas layanan publik yang melakukan pajak.
\end{abstract}

Kata Kunci: Sanksi Administrasi Pajak, Penerimaan Pajak

\section{A. Pendahuluan}

Dalam suatu negara yang pruralistik dan menganut sistem demokrasi, pajak bukan semata-mata sebagai kontribusi wajib, dan bukan pula sekadar sumbangan, atau iuran, atau partisipasi semata dari masyarakat kepada negara. Pajak menjadi unsur utama bagi perwujudan demokrasi itu sendiri. Pajak juga menjadi instrument yang menentukan bagi keberlangsungan hidup suatu negara dalam mewujudkan distribusi ekonomi dan kekayaan. Pajak merupakan 
unsur utama yang digunakan untuk mewujudkan kesejahteraan, kebahagiaan dan keadilan seluruh masyarakat ${ }^{1}$.

Penggunaan instrumen administrasi dan yuridis dalam meningkatkan kepatuhan dan kesadaran masyarakat dalam melaksanakan kewajiban perpajakan selama ini belum secara signifikan mempengaruhi dan membawa perubahan kondisi masyarakat secara luas. Penerapan sistem self assesment dalam undang-undang perpajakan sebagai salah satu upaya untuk mengubah citra pajak sebagai beban yang dipaksanakan.

Sistem self assement dalam penetapan dan penghitungan pajak pada satu sisi memberikan kesempatan dan kepercayaan kepada masyarakat untuk secara sukarela melaksanakan kewajiban perpajakannya, pada sisi lain secara psikologis memberikan beban pada masyarakat akan rumitnya prosedur administrasi perpajakan. Dalam perkembangan kebijakan pembaruan perpajakan nasional-yang lebih dikenal dengan sebutan reformasi perpajakan (tax reform) jilid ke 2, terdapat paradigma dan pendekatan dalam meningkatkan kesadaran wajib pajak.

Pemerintah telah mengambil langkah kebijakan yang bersifat persuasif. Kebijakan perpajakan yang bersifat lunak dituangkan dalam bentuk kebijakan pengampunan pajak (tax amnesty) dan yang secara khusus lebih dikenal dalam bentuk kebijakan penghapusan sanksi administrasi perpajakanini merupakan amanat Pasal 37A UU No. 28 Tahun 2007 tentang Ketentuan Umum dan Tata Cara Perpajakan (KUP). Kebijakan penghapusan pajak (tax amnesty) ini adalah penghapusan pembayaran pajak hanya sebagian dari keseluruhan kewajiban pajak, yakni atas sanksi pajaknya.

Dari uraian sebagaimana telah disampaikan di atas, yang menjadi pertanyaan kemudian adalah : apa yang menjadi tujuan dari kebijakan penghapusan sanksi administrasi perpajakan dalam kebijakan perpajakan nasional? Pertanyaan ini muncul tidak terlepas dari masih adanya perbedaan, atau bahkan salah persepsi mengenai kebijakan penghapusan sanksi administrasi perpajakan itu sendiri. Begitu pula apa yang menjadi latar belakang, dasar pertimbangan dan alasan dari adanya kebijakan pengampunan pajak - yang secara khusus lebih dikenal dalam bentuk kebijakan penghapusan sanksi administrasi perpajakan- yang dilakukan oleh pemerintah

1 Mengenai betapa penerimaan pajak merupakan salah satu andalan penerimaan negara tampak dalam RAPBN Tahun 2009 tercatat target penerimaan pajak sebesar Rp 379 trilyun. Pada RAPBN Tahun 2010 target penerimaan pajak ditetapkan sebesar Rp 494,59 triliun, penerimaa pajak ini merupakan $89 \%$ dari total penerimaan negara. Hingga akhir Maret 2008 penerimaan pajak pada DJP tercatat sebesar Rp 103,1 trilyun atau meningkat $35 \%$ dibanding periode yang sama pada tahun 2009 , yaitu sebesar $\mathrm{Rp} 76,4$ trilyun. Pencapaian penerimaan pajak hingga akhir Maret 2008 tersebut merupakan jumlah penerimaan terbesar selama enam tahun terakhir. (Harian Kompas, tanggal 4 Oktober 2008 dan 26 April 2010) 
dalam jangka panjang? Apa implikasi dari kebijakan kebijakan penghapusan sanksi administrasi perpajakan ini bagi kepatuhan wajib pajak dalam melaksanakan kewajiban perpajakannya?

Dengan berbagai permasalahan dan pertanyaan seperti tersebut di atas, maka sangat penting untuk dilakukan studi penelitian tentang kebijakan perpajakan dan menuliskannya dalam bentuk laporan penelitian dengan judul "Penghapusan Sanksi Administrasi Perpajakan sebagai Stimulus Peningkatan Penerimaan Negara dari Sektor Pajak (Studi Evaluatif Normatif Kebijakan Perpajakan Nasional)”, mengingat bahwa pajak merupakan instrumen penting sebagai sumber penerimaan suatu negara ${ }^{2}$

\section{Rumusan Permasalahan}

Berdasarkan latar belakang sebagaimana telah dijelaskan di atas, maka rumusan permasalahan dalam tulisan ini adalah :

a. Apa yang menjadi dasar, alasan, dan pertimbangan dari kebijakan penghapusan sanksi administrasi perpajakan (sunset policy) oleh fiskus ?

b. Bagaimana implementasi kebijakan kebijakan penghapusan sanksi administrasi perpajakan (sunset policy) dalam praksis perpajakan nasional ?

c. Apa relevansi dari kebijakan penghapusan sanksi administrasi perpajakan (sunset policy) sebagai stimulus penerimaan negara dari sektor pajak penghasilan $(\mathrm{PPh})$ ?

\section{Proses Penelitian}

Studi penelitian ini bertujuan untuk melakukan kajian dan analisis kebijakan pemerintah dibidang perpajakan berkenaan dengan kebijakan penghapsan sanksi administrasi perpajakan sebagai stimulus untuk meningkatkan penerimaan pajak. Untuk memenuhi tujuan dari analisis kebijakan perpajakan tersebut, penelitian ini menggunakan metode deskritif eksplanatoris,yaitu hanya membahas suatu topik dengan memberikan gambaran atas permasalahan yang telah dirumuskan dalam topik tersebut dan tidak ditujukan untuk mencari atau menguji solusi terbaik atas permasalahan yang ada.

Untuk memperoleh deskripsi yang mendalam (in deep) tentang topik penelitian ini, pencarian data dan analisis masalah dalam penelitian ini secara khusus mengenai pengaturan,

2 Mengenai betapa penerimaan pajak merupakan salah satu andalan penerimaan negara tampak dalam RAPBN Tahun 2009 tercatat target penerimaan pajak sebesar Rp 379 trilyun. Pada RAPBN Tahun 2010 target penerimaan pajak ditetapkan sebesar Rp 494,59 triliun, penerimaa pajak ini merupakan $89 \%$ dari total penerimaan negara. Hingga akhir Maret 2008 penerimaan pajak pada DJP tercatat sebesar Rp 103,1 trilyun atau meningkat $35 \%$ dibanding periode yang sama pada tahun 2009 , yaitu sebesar $\mathrm{Rp} 76,4$ trilyun. Pencapaian penerimaan pajak hingga akhir Maret 2008 tersebut merupakan jumlah penerimaan terbesar selama enam tahun terakhir. (Harian Kompas, tanggal 4 Oktober 2008 dan 26 April 2010) 
kebijakan pemerintah dan pelaksanaan kebijakan penghapusan sanksi administrasi perpajakan sebagai landasan yuridis penggunaan kewenangan fiskus dalam praksis perpajakan nasional. Analisis yang digunakan dalam penelitian ini bersifat kualitatif, yang ditujukan untuk mengeksplorasi konsekuensi permasalahan yang muncul atas kondisi yang diterangkan dalam topik penelitian ini.

Model analisis kebijakan yang digunakan dalam makalah ini adalah analisis kebijakan terintegrasi. Model analisis kebijakan terintegrasi ini adalah merupakan bentuk analisis yang mengkombinasikan gaya operasi para praktisi yang menaruh perhatian pada penciptaan dan transformasi informasi sebelum dan sesudah suatu kebijakan diambil dan dilaksanakan. Dengan demikian dalam penelitian ini yang akan dianalisis adalah bentuk kebijakan penghapusan sanksi administrasi perpajakan yang telah dilaksanakan pemerintah beserta hasil-hasil atupun implikasi yang timbul setelah kebijakan perpajakan tersebut dilaksanakan.

\section{B. Hasil Penelitian}

\section{Kebijakan Penghapusan Sanksi Administrasi Perpajakan : Paradigma Baru} Kebijakan Reformasi Perpajakan Nasional

Meningkatnya jumlah wajib pajak dan pemahaman akan hak dan kewajibannya dalam melaksanakan peraturan perundang-undangan perpajakan tidak dapat dihindarkan dan memerlukan pengaturan yang adil dan bijaksana dengan prosedur dan proses yang cepat dan sederhana, karenanya diperlukan suatu sistem yang mampu menciptakan keadilan dan kepastian hukum. Diharapkan dengan reliable, kepercayaan dunia usaha, khususnya bagi wajib pajak, baik warga negara Indonesia maupun pihak asing semakin meningkat terhadap hukum di bidang perpajakan yang berlaku di Indonesia, sehingga mereka merasa terayomi dan terlindungi secara hukum serta bersedia menanamkan modalnya dan "berdagang" di Negara Republik Indonesia. Hak-hak wajib pajak harus secara berkesinambungan diperhatikan dan dilindungi secara hukum, dan ketentuan yang dikeluarkan yang berhubungan dengan perpajakan harus lebih responsif terhadap wajib pajak yang benar dan atau beritikad baik. Masih banyak tindakan yang harus dikerjakan oleh pemerintah atau negara untuk meyakinkan agar warga negara mau melaksanakan kewajibannya, karena dunia usaha dewasa ini benar-benar dalam keadaan tidak atau kurang nyaman.

Program kebijakan penghapusan sanksi administrasi perpajakan merupakan upaya pemerintah memperluas jumlah wajib pajak untuk memperbesar penerimaan negara. Dengan kebijakan penghapusan sanksi administrasi perpajakanini, pribadi yang belum mempunyai 
NPWP didorong untuk mendaftarkan dirinya. Fasilitas yang ada pada kebijakan penghapusan sanksi administrasi perpajakan juga memungkinkan wajib pajak orang pribadi atau badan untuk membetulkan Surat Pemberitahuan Pajak Penghasilan (SPT PPh) pada tahun 2006 dan tahuntahun sebelumnya, tanpa diberikan sanksi administrasi atas laporan itu, wajib pajak tidak dikenakan denda $2 \%$ dari kewajiban per bulan dan tidak akan diperiksa karena angka yang diperbarui.

Dapat terjadi, program kebijakan penghapusan sanksi administrasi perpajakan akan terkendala apabila masih ada persepsi dan penilaian yang buruk terhadap pelayanan publik yang dilaksanakan petugas pajak. Seperti diketahui langkah Dirjen Pajak saat ini lebih sebagai persuasi bagi komunitas wajib pajak pribadi maupun institusi agar melaksanakan kewajiban dengan jujur dan konsisten. Oleh Dirjen Pajak dinyatakan bahwa kebijakan penghapusan sanksi administrasi perpajakantidak berhubungan dengan harta kekayaan wajib pajak tetapi lebih kepada penghasilan. Sesuai dengan sistem self assessment, maka wajib pajak mempunyai kewajiban untuk mendaftarkan diri pada kantor pelayanan pajak KPP atau kantor penyuluhan dan pengamatan potensi perpajakan (KP4) yang wilayahnya meliputi tempat tinggal atau kedudukan wajib pajak untuk diberikan NPWP. Pendaftaran juga dapat melalui e-register yaitu suatu cara mendaftarkan NPWP melalui internet.

Kebijakan penghapusan sanksi administrasi perpajakan ini mendapat tanggapan yang berragam dari masyarakat wajib pajak maupun para pengamat perpajakan. Semula masyarakat umumnya, khususnya wajib pajak merasa agak ragu-ragu dan khawatir tentang pelaksanaan lanjutan atas program kebijakan penghapusan sanksi administrasi perpajakantersebut. Di benak masyarakat atau wajib pajak dapat saja muncul kekhawatiran, apakah dengan melaporkan harta kekayaan nya dengan sebenarnya atau secara transparan dalam laporan perpajakan sebagaimana 'dihimbau' dalam program kebijakan penghapusan sanksi administrasi perpajakanwajib pajak akan didatangi atau diperiksa dan atau akan 'diintimidasi' oleh petugas pelayanan pajak.

Masyarakat yang beritikad baik tentu berpikir, dalam membuat suatu laporan perpajakan yang baik tentu memerlukan waktu untuk mempelajari dan menelitinya. Dan sebagai orang yang awam dalam membuat suatu laporan, khususnya di bidang perpajakan tentu dalam penyampaiannya masyarakat dapat saja keliru, baik dari kalimat maupun penempatan atau penafsiran angka-angka (jumlah) dalam penyampaiannya. Kalau sampai kekeliruan masyarakat dan atau wajib pajak berdasarkan hasil analisis petugas pajak secara sepihak dinyatakan salah dan harus membayar denda, tanpa diberi kesempatan kepadanya untuk membetulkannya tentu wajib pajak merasa akan khawatir dan dirugikan. Kekhawatiran masyarakat dan atau wajib pajak mulai terobati dan sedikit pupus setelah diterbitkannya Surat Edaran Direktur Jenderal 
Pajak Nomor SE-67/PJ/2008 tanggal 2 Desember 2008, yang menegaskan "untuk memberi kepastian hukum terhadap wajib pajak yang telah menyampaikan atau membetulkan SPT Tahunan dalam rangka kebijakan penghapusan sanksi administrasi perpajakan.

Selanjutnya ditegaskan pula dalam Surat Edaran Direktur Jenderal Pajak Nomor SE67/PJ/2008 tanggal 2 Desember 2008 mengenai prosedur usulan pemeriksaan terhadap SPT wajib pajak yang disampaikan dalam rangka kebijakan penghapusan sanksi administrasi perpajakan. Pada Surat Edaran Dirjen Pajak sebagaimana diuraikan di atas disebutkan bahwa pemeriksaan terhadap SPT tahunan PPh yang disampaikan dalam rangka kebijakan penghapusan sanksi administrasi perpajakan adalah karena adanya data atau keterangan yang dapat ditindak lanjuti adalah data atau keterangan (bukan dari hasil analisis) yang berkaitan dengan perpajakan, yaitu:

1. yang diperoleh dari instansi pemerintah, lembaga, asosiasi dan pihak lain; atau

2. yang berasal dari pihak lawan transaksi yang belum tercakup dalam SPT Tahunan PPH, dalam rangka sunset polilicy hanya dapat dilakukan berdasarkan pertimbangan Direktur Jenderal Pajak.

3. Dalam hal wajib pajak membetulkan atau mengungkapkan ketidakbenaran SPT tidak sesuai dengan surat himbauan/klarifikasi atau hasil klarifikasi account representative terhadap wajib pajak yang bersangkutan dilakukan himbauan klarifikasi berikutnya (ulang).

Mengacu pada pengertian pajak dalam UU KUP, yang di antaranya menyatakan sebagai kontribusi wajib kepada negara. Berarti, pajak bukanlah sekadar sumbangan, atau iuran, atau partisipasi semata dari masyarakat kepada negara yang boleh dijalankan atau tidak. Namun, sebagai kewajiban, maka pajak setara dengan wajib bela negara. Bila tidak dibayar, negara dapat memaksa. Tindakan ini didukung adanya UU Penagihan Pajak dengan Surat Paksa.

Sanksi pajak berupa bunga muncul jika wajib pajak (WP) tidak atau belum membayar pajak yang terutang. Padahal, tanggal jatuh tempo yang ditetapkan UU sudah lewat. Besarnya 2\% sebulan dari pokok pajak. Contoh sederhana, jika pada tahun pajak 2006 ada perhitungan pajak penghasilan $(\mathrm{PPh})$ yang belum benar, yang mengakibatkan pajak terutang Rp10 miliar berarti, hingga Desember 2008 ada sanksi bunga Rp4,8 miliar. Maka, pajak yang harus dibayar Rp14,8 miliar. Namun, dengan memanfaatkan kebijakan kebijakan kebijakan penghapusan sanksi administrasi perpajakan, sanksi pajak yang Rp 4,8 miliar akan hapus.

Penghapusan sanksi pajak tersebut tidaklah secara otomatis, tetapi harus melalui permohonan WP. Mekanismenya melalui penyampaian Surat Pemberitahuan (SPT) Tahunan 
PPh. Hal ini sesuai prinsip self assessment dalam perpajakan kita. Ada dua titik pokok pemberian kebijakan penghapusan sanksi administrasi perpajakan. Pertama, jika atas SPT Tahunan PPh tahun pajak 2006 dan sebelum-sebelumnya yang telah disampaikan WP ke Kantor Pelayanan Pajak (KPP), ternyata belum benar, sehingga setelah dihitung kembali, masih ada pajak yang harus dibayar. Adapun caranya, wajib pajak menyampaikan pembetulan atas SPT tersebut. Kedua, jika orang pribadi belum terdaftar sebagai wajib pajak. Padahal, ia telah memperoleh penghasilan yang jumlahnya di atas besaran penghasilan tidak kena pajak (PTKP) setahun. Caranya, secara sukarela (self assessment) mendaftarkan diri ke KPP untuk memperoleh nomor pokok wajib pajak (NPWP). Atas pemanfaatan kebijakan penghapusan sanksi administrasi perpajakan ini, selain sanksi pajaknya hapus, juga tidak dilakukan pemeriksaan pajak. Kecuali, jika pada kemudian hari terdapat keterangan atau data baru (novum) yang menyatakan bahwa SPT yang disampaikan tidak benar. Atau SPT menyatakan lebih bayar.

Pertanyaan yang mengemuka selama ini di masyarakat adalah, apakah kebijakan penghapusan sanksi administrasi perpajakanitu kewajiban atau hak bagi masyarakat? Pertanyaan ini muncul tidak terlepas dari masih adanya perbedaan, atau bahkan salah persepsi mengenai kebijakan penghapusan sanksi administrasi perpajakan itu sendiri. Mengacu pada pengertian pajak dalam UU KUP, yang di antaranya menyatakan sebagai kontribusi wajib kepada negara. Berarti, pajak bukanlah sekadar sumbangan, atau iuran, atau partisipasi semata dari masyarakat kepada negara yang boleh dijalankan atau tidak. Sebagai bentuk kewajiban kenegaraan warga masyarakat, maka pajak setara dengan wajib bela negara. Bila tidak dibayar, negara dapat memaksa. Tindakan ini didukung adanya UU Penagihan Pajak dengan Surat Paksa.

Dalam pelaksanaannya, kewajiban perpajakan yang berbasis self assessment, tidak tertutup kemungkinan ada penghasilan atau biaya yang belum dilaporkan dalam SPT. Penyebabnya bisa bermacam-macam. Akibatnya, jika dibetulkan SPT-nya, maka masyarakat tentu akan terbeban mengeluarkan dana yang banyak. Karena selain membayar pokok pajak, juga atas sanksi bunga $2 \%$ sebulan. Berangkat dari esensi kebijakan penghapusan sanksi administrasi perpajakan yakni diberikannya penghapusan sanksi pajak kepada masyarakat, pemberian fasilitas ini berlaku umum kepada semuanya sebagai amanat UU. Dalam konteks ini, melalui kebijakan penghapusan sanksi administrasi perpajakan, negara akan memberikan sesuatu kepada masyarakat, yakni hapusnya sanksi pajak. Jadi, bukan sebaliknya, di mana masyarakat akan membayar sanksi pajak. Masyarakat akan mendapatkan sesuatu dari negara, sehingga kedudukan kebijakan penghapusan sanksi administrasi perpajakan sebenarnya merupakan hak istimewa bagi rakyat. 


\section{Signifikansi Kebijakan Penghapusan Sanksi Administrasi Perpajakan terhadap Peningkatan Jumlah Wajib Pajak}

Kebijakan perpajakan yang dilakukan pemerintah berupa penghapusan sanksi administrasi perpajakan kepada wajib pajak, yang lebih dikenal dengan Sunset Policy ini merupakan kebijakan dalam rangka keterbukaan untuk melaksanakan kewajiban di bidang perpajakan. Kebijakan penghapusan sanksi administrasi perpajakan merupakan fasilitas penghapusan sanksi pajak penghasilan orang pribadi atau badan. Penghapusan sanksi administrasi perpajakan tersebut berupa bunga atas kekurangan pembayaran pajak yang dapat dinikmati oleh masyarakat, baik yang belum memiliki Nomor Pokok Wajib Pajak (NPWP) maupun yang telah memiliki NPWP pada tanggal 1 Januari 2008. Namun, kebijakan pemerintah sebagai bentuk fasilitas bagi wajib pajak ini dibatasi pelaksanaannya hingga akhir tahun 2008 .

Dalam rangka untuk meningkatkan penerimaan pajak dan memberikan dorongan bagi peningkatan kepatuhan wajib pajak untuk melaksanakan kewajiban perpajakannya, pemerintah memberikan kewenangan kepada Direktur Jenderal Pajak untuk mengeluarkan kebijakan kebijakan kebijakan kebijakan penghapusan sanksi administrasi perpajakan. Kebijakan ini merupakan bentuk realisasi kewenangan yang diberikan oleh Undang-undang sebagaimana diatur dalam Pasal 37A Undang-Undang No. 28 Tahun 2007 tentang Perubahan Ketiga atas Undang-Undang No. 6 Tahun 1983 tentang Ketentuan Umum dan Tata Cara Perpajakan (UU KUP).

Selain itu, peraturan pelaksanaannya ditetapkan dalam Peraturan Menteri Keuangan No. 66 Tahun 2008 tentang Tata Cara Penyampaian dan Pembetulan Surat Pemberitahuan (SPT) serta Persyaratan Wajib Pajak yang Dapat Diberikan Sanksi Administrasi dalam Rangka Penerapan Pasal 37A UU No. 28 Tahun 2007 tentang KUP. Untuk melaksanakan amanat yang ditetapkan oleh Undang-undang dan memastikan tidak ada pelanggaran di lapangan, Dirjen Pajak telah menerbitkan Peraturan Dirjen Pajak No. 30 Tahun 2008.

Dalam Perdirjen Pajak 30/2008 disebutkan, wajib pajak yang memanfaatkan kebijakan penghapusan sanksi administrasi perpajakan memperoleh fasilitas berupa: penghapusan sanksi pajak berupa bunga atas keterlambatan pembayaran pajak yang tidak atau kurang dibayar; penghentian pemeriksaan pajak, dalam hal pemeriksa pajak belum menyampaikan Surat pemberitahuan Hasil Pemeriksaan (SPHP); tidak dilakukan pemeriksaan pajak sehubungan dengan penyampaian atau pembetulan SPT Tahunan $\mathrm{PPh}$, kecuali terdapat data atau informasi lain yang menyatakan bahwa SPT Tahunan PPh yang disampaikan tidak benar; dan data dan/atau informasi yang tercantum dalam SPT dalam rangka kebijakan penghapusan sanksi 
administrasi perpajakantidak dapat digunakan sebagai dasar untuk menerbitkan surat ketetapan pajak-pajak lainnya.

Tabel 5. Fasilitas Kebijakan Penghapusan Sanksi Administrasi Perpajakan bagi Wajib Pajak

Orang pribadi yang belum memiliki NPWP pada tanggal 1 Januari 2008, dapat menikmati fasilitas kebijakan penghapusan sanksi administrasi perpajakan (Sunset Policy), apabila:

1. secara sukarela mendaftarkan diri untuk memperoleh NPWP dalam tahun 2008;

2. tidak sedang dilakukan pemeriksaan bukti permulaan, penyidikan, penuntutan, atau pemeriksaan pengadilan atas tindak pidana di bidang perpajakan;

3. mengisi SPT tahunan PPh orang pribadi untuk tahun pajak 2007 dan tahun-tahun sebelumnya terhitung sejak memenuhi persyaratan subjektif dan objektif paling lambat tanggal 31 Maret 2009;

4. dan melunasi seluruh pajak yang kurang dibayar sebelum SPT tahunan PPh-nya disampaikan.

Wajib pajak orang pribadi maupun wajib pajak badan yang telah memiliki NPWP pada tanggal 1 Januari 2008 juga dapat menikmati fasilitas kebijakan penghapusan sanksi administrasi perpajakan (Sunset Policy), apabila:

a. belum diterbitkan surat ketetapan pajak; belum dilakukan pemeriksaan atau dalam hal sedang dilakukan pemeriksaan, pemeriksa pajak belum menyampaikan Surat Pemberitahuan Hasil Pemeriksaan (SPHP);

b. tidak sedang dilakukan pemeriksaan bukti permulaan, penyidikan, penuntutan, atau pemeriksaan pengadilan atas tindak pidana di bidang perpajakan;

c. telah dilakukan pemeriksaan bukti permulaan, tetapi pemeriksaan bukti permulaan tersebut tidak dilanjutkan dengan tindakan penyidikan karena tidak ditemukan adanya bukti permulaan tentang tindak pidana di bidang perpajakan;

d. membetulkan SPT tahunan PPh tahun pajak 2006 dan/atau tahun-tahun sebelumnya dalam tahun 2008 dengan tambahan pembayaran pajak;

e. dan melunasi seluruh pajak yang kurang dibayar sebelum SPT Tahunan PPh-nya disampaikan.

Sumber data: Humas Dirjen Pajak

Kebijakan pemerintah di bidang perpajakan dalam bentuk kebijakan penghapusan sanksi administrasi perpajakan (sunset policy) ini memberikan fasilitas penghapusan sanksi 
pajak kepada wajib pajak pribadi maupun wajib pajak badan. Wajib pajak orang pribadi yang belum memiliki Nomor Pokok Wajib Pajak (NPWP) pada tanggal 1 Januari 2008 dapat menikmati fasilitas kebijakan penghapusan sanksi administrasi perpajakan, apabila telah memenuhi syarat-syarat yang telah ditentukan dalam peraturan Direktur Jendral Pajak No. 30 Tahun 2008 wajib pajak yang melaksanakan kewajiban perpajakannya pada periode kebijakan penghapusan sanksi administrasi perpajakanini akan memperoleh pengecualian untuk tidak akan diperiksa pembukuannya dan dihapuskan sanksi-sanksi administrasinya apabila kemungkinan terdapat perbedaan dalam penghitungan, penetapan maupun pelaporan pajaknya untuk tahun pajak sebelumnya.

Kebijakan kebijakan penghapusan sanksi administrasi perpajakan (sunset policy) merupakan salah satu bagian dari paket kebijakan reformasi perpajakan nasional yang dirancang dan mulai dilaksanakan pada periode awal tahun 2008. Reformasi perpajakan yang pertama pada tahun 1983 dan dilanjutkan dengan reformasi perpajakan tahun 2008, adalah perubahan yang mendasar di segala aspek perpajakan. Reformasi perpajakan yang sekarang menjadi prioritas menyangkut modernisasi administrasi perpajakan jangka menengah (tiga hingga enam tahun) dengan tujuan tercapainya: pertama, tingkat kepatuhan sukarela yang tinggi. Kedua, kepercayaan terhadap administrasi perpajakan yang tinggi. Dan, ketiga, produktivitas aparat perpajakan yang tinggi.

Dalam jangka pendek, upaya-upaya yang dilakukan adalah dimungkinkannya WP untuk menyampaikan SPT secara elektronik (e-filing). Dalam rangka peningkatan pelayanan permohonan restitusi kepada WP, sedang dikaji agar permohonannya dapat diberikan cukup dengan penelitian saja. Di samping itu, kini sedang digodok upaya untuk mengefektifkan penagihan pajak, yakni kemungkinan penetapan pihak ketiga yang menguasai harta penunggak pajak sebagai penanggung pajak.

Langkah reformasi yang sangat signifikan adalah pembentukan kantor wajib pajak besar. Guna memberikan pelayanan dan pengawasan yang lebih baik terhadap WP Besar yang memberikan kontribusi yang relatif besar terhadap penerimaan pajak, Direktorat Jenderal Pajak membentuk Kantor Wilayah dan KPP WP Besar . Pada KPP WP Besar tersebut dibentuk account representative (AR) yang bertujuan untuk mengetahui segala tingkah laku, ruang lingkup bisnis, dan segala sesuatu yang berkaitan dengan hak dan kewajiban perpajakan wajib 
pajak yang diawasinya (knowing your taxpayer) dan pelayanan kepada WP dapat dilakukan secara tuntas pada satu meja ${ }^{3}$.

Di samping itu, peningkatan pelayanan terhadap wajib pajak dilakukan dengan membangun online system yang menyangkut pembayaran pajak (e-payment), pendaftaran NPWP (e-registration), serta pelaporan SPT (e-filing) sehingga WP tidak perlu lagi datang ke kantor pajak, namun cukup melakukan kegiatan tersebut secara online dari rumah/kantor mereka. Dengan demikian, persinggungan antara wajib pajak dengan petugas dapat diminimalisir dan bermanfaat bagi semua pihak. Di samping itu, reformasi pengawasan terhadap pemenuhan kewajiban perpajakan dilakukan meliputi: pertama, pembentukan bank data (alat pengawasan). Kedua, mengembangkan E-mapping dan smart-mapping. Dan, ketiga, melakukan law enforcement, antara lain penyanderaan (gejzling) dan penyidikan.

Dari keseluruhan kinerja pemerintah di bidang perpajakan, pada hakikatnya merupakan upaya memberikan kesejahteraan yang sebesar-besarnya dan seluas-luasnya kepada seluruh rakyat Indonesia. Dan, hal ini merupakan orientasi dan tujuan kerja paling utama dari pemerintah. Reformasi yang dilakukan ke depan direncanakan merupakan kelanjutan dari reformasi perpajakan yang sejauh ini telah dimulai, dan dirancang agar sistematis dan sustainable sehingga ketahanan fiskal dapat lebih terjamin.

\section{Relevansi Kebijakan Penghapusan Sanksi Administrasi Perpajakan sebagai Stimulus Peningkatan Penerimaan Pajak}

Tanpa mengingkari fenomena-fenomena riil di masyarakat sekarang ini yang masih terpuruk dalam krisis ekonomi, pemerintah dengan kebijakan fiskal mengisyaratkan untuk dapat memelihara dan mempertahankan disiplin kebijakan makroekonomi sebagai kunci penting dalam menciptakan lingkungan yang kondusif bagi upaya pemulihan. Ini adalah faktor penting untuk mendukung pemulihan sektor riil dan dunia usaha. Kebijakan fiskal melalui penerimaan dan belanja negara merupakan instrumen ampuh guna mengambil tindakan bagaimana output nasional dipergunakan untuk sebesar-besar kemakmuran rakyat.

Oleh James Tobin, pemenang hadiah Nobel Ekonomi, disimpulkan bahwa kebijakan fiskal mengatur kewajiban warga negara dalam bidang perpajakan untuk dialokasikan kepada aktivitas ekonomi masyarakat secara adil dan merata. Untuk itu, kebijakan fiskal terus

3 Hasil wawancara dengan Kepala Bidang Penyuluhan Perpajakan Direktorat Jendral Pajak 28 September 2009 
diupayakan agar sehat, menggali potensi sendiri, dan mengurangi ketergantungan pembiayaan pembangunan dari pinjaman dan bantuan dari negara asing ${ }^{4}$.

Pada tahun 2004, Pemerintah Indonesia menargetkan penurunan target defisit hingga lebih kurang 1 persen dari Produk Domestik Bruto (PDB) agar semakin sehat. Penurunan tersebut telah dilaksanakan secara konsisten sejak tahun 2000. Dalam tahun 2000, dari yang semula diperkirakan sekitar 4,8 persen dari PDB, dalam realisasinya hanya mencapai sekitar 1,6 persen dari PDB. Dalam tahun-tahun berikutnya, rasio defisit anggaran terhadap PDB dimaksud dapat ditekan menjadi 2,8 persen pada tahun 2001, dan bahkan dapat diturunkan lagi hingga mencapai sekitar 1,7 persen dari PDB pada tahun 2002.

Pada 2003, defisit anggaran ditargetkan sekitar 1,8 persen dari PDB. Salah satu kunci dari pencapaian target defisit 1\% pada tahun 2004 adalah penerimaan dari perpajakan. Kebijakan perpajakan dalam tahun anggaran 2004 akan difokuskan pada pembaruan administrasi perpajakan (tax administration reform) yang sudah dimulai sejak tahun 2000. Tujuan dari kebijakan ini adalah meningkatkan efektivitas pemungutan pajak serta memperluas basis pajak, tanpa mengganggu sektor usaha. Pemerintah juga memiliki komitmen agar kebijakan perpajakan dilakukan dengan tidak memberikan beban tambahan kepada pelaku ekonomi.

Hasil dari berbagai kebijakan tersebut tampak dari penerimaan Anggaran Pendapatan dan Belanja Negara (APBN) dari sektor perpajakan yang meningkat dari waktu ke waktu. Dalam waktu tiga tahun saja (2001-2003), total penerimaan negara lebih besar dari 10 tahun periode 1990-2000. Sejak itu pula rasio perpajakan melonjak dari 10 persen ke 13 persen pada tahun 2003. Ditambah dengan penerimaan pajak daerah (2 persen dari PDB), sebetulnya rasio perpajakan Indonesia sudah sebanding dengan pencapaian negara-negara tetangga.

Salah satu indikator hasil reformasi perpajakan dari sisi kuantitatif di samping rasio perpajakan dan penerimaan perpajakan, adalah pertambahan jumlah wajib pajak (WP) orang pribadi. Selama sembilan tahun (1991-2000) pertambahan jumlah wajib pajak orang pribadi (lebih kurang 549 ribu orang) lebih rendah daripada dua tahun terakhir (2001-2002), yakni berjumlah 551 ribu. Demikian juga dengan penerimaan perpajakan nonmigas selama periode yang sama menunjukkan hasil searah. Kebijakan administrasi perpajakan untuk tahun 2003 dan 2004 terus melanjutkan langkah-langkah intensifikasi dan ekstensifikasi wajib pajak, baik itu penambahan wajib pajak efektif, pemeriksaan, maupun penagihan tunggakan pajak.

Selama triwulan I tahun 2003, pertambahan WP terdaftar adalah 6.245 WP badan dan 36.617 WP orang pribadi baru, dengan penerimaan masing-masing Rp 57,129 miliar dan Rp

${ }^{4}$ Anggito Abimanyu, Reformasi Perpajakan Perlu Dukungan Masyarakat, Artikel harian Kompas tanggal 23 Nopember 2008 
6,096 miliar. Dalam waktu yang sama telah diterbitkan surat ketetapan pajak senilai Rp 4,34 triliun dan dicairkan tunggakan pajak sebesar Rp 1,179 triliun. Pemerintah sangat menyadari bahwa jumlah wajib pajak orang pribadi yang saat ini baru berjumlah di bawah 2 juta masih sangat di bawah potensi. Demikian juga tingkat kepatuhan wajib pajak dalam mengisi surat pemberitahuan tahunan (SPT) dengan benar juga masih sangat memprihatinkan. Untuk itulah reformasi di bidang administrasi perpajakan akan menjangkau seluas-luasnya warga negara mampu yang belum menjadi wajib pajak dan menjadi wajib pajak patuh.

Reformasi perpajakan dengan langka awal berupa kebijakan penghapusan sanksi administrasi perpajakan merupakan bentuk kebijakan perpajakan yang memberikan fasilitas pengampunan pajak, khususnya pajak penghasilan. Dengan kebijakan ini diharapkan dalam jangka panjang dapat mempengaruhi kesadaran dan kepatuhan wajib pajak dalam melaksanakan kewajiban perpajakannya. Pada sisi lain juga akan meningkatkan jumlah wajib pajak yang berasal dari subyek pajak potensial yang telah memenuhi kewajiban administrasi perpajakan dalam bentuk pendaftaran diri dengan memiliki NPWP. Peningkatan jumlah wajib pajak yang telah menggunakan kesempatan pada saat pelaksanaan kebijakan penghapusan sanksi administrasi perpajakandiharapkan juga dapat mendorong peningkatan penerimaan pajak secara signifikan. (lihat table 12.)

Tabel 6. Realisasi Penerimaan Pajak

Setelah Kebijakan Penghapusan Sanksi Administrasi Perpajakan(Semester I 2008)

\begin{tabular}{|c|c|c|}
\hline Jenis Penerimaan & $\begin{array}{c}\text { Jumlah Penerimaan } \\
\text { (dalam miliar rupiah) }\end{array}$ & Presentase Pertumbuhan \\
\hline PPh non Migas & $129.666,92$ & 39,44 \\
\hline PPN dan PPnBM & $87.117,26$ & 49,12 \\
\hline BPHTB & $2.224,47$ & 40,42 \\
\hline
\end{tabular}

Sumber: Direktorat Jenderal Pajak RI

Dari data yang diperoleh sebagai realisasi pelaksanaan kebijakan penghapusan sanksi administrasi perpajakan, pertumbuhan penerimaan pajak tersebut merupakan hasil dari kegiatan modernisasi, intensifikasi dan ekstensifikasi yang dilaksanakan Ditjen Pajak. Kegiatan intensifikasi pajak dilakukan melalui penggalian potensi dengan pembuatan mapping, profile, dan benchmark wajib pajak penentu penerimaan di setiap Kantor Pelayanan Pajak (KPP) yang dimulai sejak April 2007. "Kami juga menggali potensi penerimaan secara sektoral diprioritaskan terhadap sektor-sektor yang booming," ungkap Damin Nasution-Dirjen Pajak saat 
ini-. Dalam catatan Ditjen Pajak disebutkan, proporsi penerimaan netto pajak tanpa PPh Migas ini terhadap total rencana setahun (APBN-P 2008), sebesar 48\%. Darmin mengklaim angka ini jauh di atas rata-rata proporsi penerimaan periode yang sama selama lima tahun terakhir sebesar $41,51 \%$.

Reformasi perpajakan adalah perubahan yang mendasar di segala aspek perpajakan. Reformasi perpajakan yang sekarang menjadi prioritas menyangkut modernisasi administrasi perpajakan jangka menengah (tiga hingga enam tahun) dengan tujuan tercapainya: pertama, tingkat kepatuhan sukarela yang tinggi. Kedua, kepercayaan terhadap administrasi perpajakan yang tinggi. Dan, ketiga, produktivitas aparat perpajakan yang tinggi. Reformasi yang dilakukan ke depan direncanakan merupakan kelanjutan dari reformasi perpajakan yang sejauh ini telah dimulai, dan dirancang agar sistematis dan berkelanjutan (sustainable), sehingga ketahanan fiskal dapat lebih terjamin.

Sementara tingkat keberhasilan kerja yang dilakukan pemerintah termasuk di dalam reformasi perpajakan akan sangat ditentukan oleh kesadaran kita semua, seluruh warga bangsa, untuk secara tulus dan ikhlas memenuhi kewajiban perpajakannya dan memperkuat fondasi untuk mempersiapkan exit strategy dari program Dana Moneter Internasional (IMF) yang sekarang ada. Bagi pemerintah, persoalan program exit strategy terkait dengan pembenahan kebijakan fiskal adalah melanjutkan program reformasi perpajakan untuk mendukung pemulihan ekonomi yang terbukti telah memberikan hasil selama ini.

\section{Penutup}

\section{Kesimpulan}

Berdasarkan analisis kebijakan perpajakan sebagaimana telah disampaikan pada sub bagian pembahasan di atas, maka dapat dirumuskan beberapa kesimpulan sebagai berikut :

a. Kebijakan penghapusan sanksi administrasi perpajakan sebagai kebijakan pemerintah dibidang perpajakan merupakan bentuk realisasi kewenangan yang diberikan oleh Pasal 37A Undang-Undang No. 28 Tahun 2007 tentang Perubahan Ketiga atas UndangUndang No. 6 Tahun 1983 tentang Ketentuan Umum dan Tata Cara Perpajakan (UU KUP) dengan Peraturan Menteri Keuangan No. 66 Tahun 2008 tentang Tata Cara Penyampaian dan Pembetulan Surat Pemberitahuan (SPT) serta Persyaratan Wajib Pajak yang Dapat Diberikan Sanksi Administrasi sebagai peraturan pelaksanaannya. Untuk melaksanakan amanat yang ditetapkan oleh Undang-Undang dan memastikan tidak ada pelanggaran di lapangan, Dirjen Pajak juga telah menerbitkan Peraturan Dirjen Pajak No. 30 Tahun 2008. 
b. Kebijakan penghapusan sanksi administrasi perpajakan (Sunset Policy) merupakan kebijakan dalam rangka keterbukaan untuk melaksanakan kewajiban di bidang perpajakan. Kebijakan penghapusan sanksi administrasi perpajakan merupakan fasilitas penghapusan sanksi pajak penghasilan orang pribadi atau badan.

c. Implementasi kebijakan penghapusan sanksi administrasi perpajakantelah mendorong bagi adanya tingkat pertumbuhan Wajib Pajak dan penerimaan pajak. Kenaikan jumlah Wajib Pajak setelah adanya kebijakan penghapusan sanksi administrasi perpajakan tercatat sebesar 6,126,373 orang dan Badan, mengalami kenaikanhampir 100\%, jika dibadingkan pada periode tahun 2002. Begitu pula pemnerimaan pajak dari PPh mengalami kenaikan lebih dari $10 \%$ jika dibandingkan dengan penerimaan pajak periode tahun 2002. DJP mencatat penerimaan negara dari sektor pajak setelah kebijakan penghapusan sanksi administrasi perpajakanberjumlah 715,8 trilyun,yaitu sebesar 73,6\% dari APBN.

\section{Rekomendasi}

Dengan mengacu pada rumusan kesimpulan sebagai hasil studi evaluatif dan analisis yang telah dilakukan terhadap permasalahan yang menjadi topik penelitian ini, maka rekomendasi dapat diberikan adalah sebagai berikut:

a. Reformasi perpajakan dengan langka awal berupa kebijakan penghapusan sanksi administrasi perpajakan merupakan bentuk stimulus di bidang perpajakan yang memberikan fasilitas kebijakan penghapusan sanksi administrasi perpajakanpajak, khususnya pajak penghasilan. Dengan kebijakan ini diharapkan dalam jangka panjang dapat mempengaruhi kesadaran dan kepatuhan wajib pajak dalam melaksanakan kewajiban perpajakannya. Peningkatan jumlah wajib pajak yang telah menggunakan kesempatan pada saat kebijakan penghapusan sanksi administrasi perpajakandiharapkan juga dapat mendorong peningkatan penerimaan pajak secara signifikan.

b. Reformasi perpajakan yang dilakukan adalah perubahan yang mendasar di segala aspek perpajakan. Prioritas reformasi perpajakan ke 2 yang dilakukan sekarang adalah meliputi: modernisasi administrasi perpajakan jangka menengah (tiga hingga enam tahun), sehingga untuk mencapai tujuan tersebut harus didukung oleh tercapainya: pertama, tingkat kepatuhan sukarela yang tinggi. Kedua, kepercayaan terhadap administrasi perpajakan yang tinggi. Dan, ketiga, produktivitas aparat perpajakan yang tinggi. Reformasi yang dilakukan ke depan direncanakan merupakan kelanjutan dari reformasi perpajakan yang sejauh ini telah dimulai, dan dirancang agar sistematis dan sustainable sehingga ketahanan fiskal dapat lebih terjamin. 
c. Tingkat keberhasilan kerja yang dilakukan pemerintah termasuk di dalam reformasi perpajakan akan sangat ditentukan oleh kesadaran seluruh komponen negara, seluruh warga bangsa yang secara tulus dan ikhlas memenuhi kewajiban perpajakannya dan memperkuat fondasi untuk mempersiapkan program exit strategy terkait dengan pembenahan kebijakan fiskal untuk mendukung pemulihan ekonomi yang terbukti telah memberikan hasil selama ini. 


\section{Daftar Pustaka}

Adam Smith (diedit oleh Edwin Cannan), An Inquiry into the Nature and Causes of the Wealth of Nations, New York: The Modern Library, 1985

Agustin Asikin, Tina Noorjaya (editor), Pajak, Citra, dan Bebannya, Bina Rena Pariwara, Jakarta, 1990

Diaz Priantara, Pemeriksaan dan Penyidikan Pajak, Penerbit Djambatan, Jakarta, 2000

Ernest Baker, The Politics of Aristotle, Oxford University Press, London-New York, 1984

Frans Magnis Suseno, Etika Politik, Prinsip-prinsip Moral Dasar Kenegaraan Modern, Pustaka Gramedia, Jakarta, 1991

Glenn T. Jenkins \& Ganghadar P., Public Finance in Open Economics, Harvard International Tax Program, Harvard Institute for International Development, 1997

Goedhart, C. (Terjemahan : Ratmoko), Garis-garis Besar Ilmu Keuangan Negara, Penerbit Djambatan, Jakarta, 1973

Guritno Mangkoesoebroto, Ekonomi Publik, BP FE UGM, Yogyakarta, 1993

Hector S. de Leon, Fundamental of Taxation, Rex Book Store, Manila, Philipinnes, 1993

Hill Hal, Transformasi Ekonomi Indonesia Sejak 1966, Tiara Wacana Yogyakarta, 1996

\section{Makalah dan Artikel}

Anggito Abimanyu, Reformasi Perpajakan Perlu Dukungan Masyarakat, Artikel Harian Kompas tanggal 23 Nopember 2008

Anwar Nasution, Perkembangan Perekonomian Indonesia 1978-1991, Dampak Jangka Pendek dan Implikasi Jangka Panjang, Prisma No. 9 Tahun 1991

Dadut Priyambodo, Paksa Badan Atau Krisis Lagi ?, Harian Kompas Tanggal 11 Oktober 2000

Hussein Kartasasmita, Pemeriksaan Pajak dan Reformasi, Majalah Hukum Bisnis, Vol. 3 Tahun 1998

Reformasi Perpajakan Perihal BPSP dan Penagihan Dengan Surat Paksa, Majalah Hukum Bisnis, Vol. 4 Tahun 1998 